\title{
HISTORICAL RECORDS OF NEOTTIA CORDATA AND HAMMARBYA PALUDOSA, NEW IN THE KAZAKHSTAN FLORA
}

\author{
Serik A. Kubentayev ${ }^{1}$, Petr G. Efimov ${ }^{2} \mathbb{D}$, Daniyar T. Alibekov ${ }^{1}$ (D) \\ ${ }^{1}$ Astana Botanical Garden, Kazakhstan \\ e-mail:kubserik@mail.ru,dansilvaforest@mail.ru \\ ${ }^{2}$ Komarov Botanical Institute of RAS, Russia \\ e-mail:efimov81@mail.ru
}

Received: 27.01.2021. Revised: 17.04.2021. Accepted: 18.04.2021.

\begin{abstract}
The article provides data on two orchid species, new in the flora of Kazakhstan. These are Neottia cordata from Markakol State Nature Reserve (East Kazakhstan) and Hammarbya paludosa from Mugodzhary Mts. (West Kazakhstan). The nearest previously known locations of Hammarbya paludosa are more than $500 \mathrm{~km}$ northwards from the reported location. The nearest previously known location of Neottia cordata is ca. $300 \mathrm{~km}$ north-east of the reported location. The new sites of these species are based on historical herbarium specimens collected in 1908 and 1934 and stored in the herbaria of LE, NS, and MW.
\end{abstract}

Key words: Central Asia, Listera cordata, Kazakh Altai, Mugodzhar, new records, orchid, Orchidaceae

Orchidaceae Juss. is one of the largest families in the world, with about 880 genera and more than 25000 species (Cribb et al., 2003). According to Abdulina (1998), 30 orchid species are known in Kazakhstan. The study of the Orchidaceae family receives an increased attention, since many species are rare and threatened plants. Most studies are conducted in the tropics, while in Central Asian countries, studies on the orchid family are rare (Khapugin, 2020).

Since 2020, we have been working on the revision of orchids in Kazakhstan based on the material stored in herbaria in Russia and Kazakhstan: LE, MW, TK, MHA, SVER, KUZ, ALTB, AA, NUR, KG, KSPI, NS, NSK. The revision of the herbaria of the Komarov Botanical Institute of RAS (LE), Central Siberian Botanical Garden (NS, NSK), Moscow State University (MW) (Seregin, 2020) has resulted in the discovery of two new locations of rare species, namely Hammarbya paludosa (L.) Kuntze, and Neottia cordata (L.) Rich. Neither of the species was previously listed for the flora of Kazakhstan (Kuznetsov \& Pavlov, 1958; Abdulina, 1998).

Neottia cordata (syn.: Listera cordata (L.) R.Br.), a rare species with a Circumpolar distribution, is widely distributed in the subarctic and temperate zones in the Northern Hemisphere (Kotilínek et al., 2017). The herbarium specimen was collected in Kurchum District of the East Kazakhstan Region in 1908. On the la- bel of the herbarium specimen is given: Semipalatinsk Region, Ust'-Kamennogorskiy County, village of Elovka, the northern shore of the Lake Marka-Kul' $\left(48.806^{\circ} \mathrm{N}, 85.686^{\circ} \mathrm{E}\right.$ ), fir (Abies sibirica Ledeb.) forest, near peat land, 04.07.1908, A.N. Sedelnikov (LE!, NS!) (Fig. $1 \mathrm{~S})$. The location is situated on the southern spur of the Kurchumsky Mt. Ridge, near Lake Markakol (Fig. 3S). This site has a protected status of the Markakol State Nature Reserve. The nearest location of Neottia cordata is known $300 \mathrm{~km}$ north-east, in the Republic of Altai, Russia (Altai State Nature Reserve, upper reaches of the River Bayas - MW 47738!). Neottia cordata may be found in the KatonKaragay National Park, because this area borders the Markakol State Nature Reserve. These large areas are occupied by relict fir ( $A$. sibiri$c a$ ) forests (Sultanova et al., 2014), which are preferred by this species (Tsiftsis et al., 2019).

Hammarbya paludosa is a Holarctic species with a disjunctive range covering temperate regions of Eurasia and North America (Bragina \& Vakhrameeva, 2008; Vakhrameeva et al., 2008). The new location belongs to the Mugalzhar District of the Aktyubinsk Region. We report this species on the basis of the herbarium specimen collected during the Mugodzhar-Emben expedition under the leadership of G.I. Dokhman. On the herbarium specimen label is written: Aktyubinsk Region, site Urkach $\left(49.262^{\circ} \mathrm{N}\right.$, 
$\left.58.187^{\circ} \mathrm{E}\right)$, on the peat moss bog, 01.09.1934, U.N. Samseev, №514 (MW 0816996!) (Fig. 2S). The site Urkach is located on the elevated watersheds of the River Emba, River Ilek, and the tributaries of the River Or, northwest of the Mugodzhary Mts. (Fig. 3S; Rusanov, 1948). This specimen was initially misidentified as Microstylis monophyllos (L.) Lindl., and re-identified as Hammarbya paludosa in 2002 (Fig. 2S).

The nearest locations of Hammarbya paludosa are known near Lake Kukai, $530 \mathrm{~km}$ northwards, in the Chelyabinsk Region, Russia (Kulikov, 2005) and $510 \mathrm{~km}$ northwest, near the village Mebel'nyi, Republic of Bashkiria, Russia (Mirkin, 2011). In Kazakhstan, new records of this species may be found in bogs of the Kostanay Region, including the Nauryzim State Nature Reserve, as well as in the Sphagnum bogs of the West Kazakhstan Region.

The presented records of two rare species of Hammarbya paludosa and Neottia cordata based on the material of herbarium collections can be used for navigation in field studies, which are required to confirm the current species occurrence in Kazakhstan. Despite the possible extinction of these species in Kazakhstan, we consider it necessary to include them in the Red Data Book of the Republic of Kazakhstan, because otherwise these species could be left without legal protection status in case of their re-discovery.

\section{Acknowledgments}

This study was supported by the Ministry of Ecology, Geology and Natural Resources of the Republic of Kazakhstan (Program, IRN: BR10264471).

\section{Supporting Information}

The map of the new locations of Hammarbya paludosa and Neottia cordata and digitised files of their herbarium specimens (Electronic Supplement. Digitised files of herbarium specimens and a map of the new locations of Hammarbya paludosa and Neottia cordata) may be found in the Supporting Information.

\section{References}

Abdulina S.A. 1998. Checklist of vascular plants of $\mathrm{Ka}$ zakhstan. Almaty. 187 p. [In Russian]

Bragina E.A., Vakhrameeva M.G. 2008. Hammarbya paludosa. In: Biological flora of the Moscow region. Vol. 16. Tula: Grif \& Ko. P. 26-42. [In Russian]

Cribb P.J., Kell S.P., Dixon K.W., Barrett R.L. 2003. Orchid conservation: A global perspective. In: K.W. Dixon, S.P. Kell, R.L. Barrett, P.J. Cribb (Eds.): Orchid conservation. Kota Kinabalu: Natural History Publications (Borneo). P. 1-24.

Khapugin A.A. 2020. A global systematic review on orchid data in Protected Areas. Nature Conservation Research 5(Suppl.1): 19-33. DOI: 10.24189/ncr.2020.019

Kotilínek M., Tatarenko I., Jersáková J. 2018. Biological Flora of the British Isles: Neottia cordata. Journal of Ecology 106(1): 444-460. DOI: 10.1111/1365-2745.12895

Kulikov P.V. 2005. Synopsis of the flora of the Chelyabinsk Region (vascular plants). Yekaterinburg: Geotour. 537 p. [In Russian]

Kuznetsov N.M., Pavlov N.V. 1958. Orchidaceae Juss. In: N.V. Pavlov (Ed.): Flora of Kazakhstan. Vol. 2. AlmaAta: KASSR Publishing House. 353 p. [In Russian]

Mirkin B.M. (Ed.). 2011. Red Data Book of the Republic of Bashkortostan: Plants and fungi. Vol. 1. Ufa: MediaPrint. 384 p. [In Russian]

Rusanov F.N. 1948. Sphagnum swamps of the Dzhaksy-Urkach site. Botanicheskii Zhurnal 6: 605-609. [In Russian]

Seregin A.P. (Ed.). 2020. Digital herbarium of MSU: Electronic resource. Moscow: Moscow State University. Available from https://plant.depo.msu.ru/

Sultanova B.M., Dimeeva L.A., Islamgulova A.F. 2014. Botanical diversity of the Southern Altai in the conditions of climate change. Problems of botany in Southern Siberia and Mongolia 13: 219-223. [In Russian]

Tsiftsis S., Djordjević V., Tsiripidis I. 2019. Neottia cordata (Orchidaceae) at its southernmost distribution border in Europe: Threat status and effectiveness of Natura 2000 Network for its conservation. Journal for Nature Conservation 48: 27-35. DOI: 10.1016/j.jnc.2019.01.006

Vakhrameeva M.G., Tatarenko I.V., Varlygina T.I., Torosyan G.K., Zagulskii M.N. 2008. Orchids of Russia and adjacent countries (within the borders of the former USSR). Liechtenstein: A.R.G. Gantner Verlag K.G. 690 p. 
ИСТОРИЧЕСКИЕ НАХОДКИ NEOTTIA CORDATA И НAMMARBYA PALUDOSA, НОВЫХ ДЛЯ ФЛОРЫ КАЗАХСТАНА

\author{
С. А. Кубентаев $1 \mathbb{D}$, П. Г. Ефимов² ${ }^{\mathbb{D}}$, Д. Т. Алибеков ${ }^{1}$ \\ ${ }^{1}$ Астанинский ботанический сад, Казахстан \\ e-mail:kubserik@mail.ru,dansilvaforest@mail.ru \\ ${ }^{2}$ Ботанический институт имени В.Л. Комарова РАН, Россия \\ e-mail:efimov81@mail.ru
}

Приводятся сведения о двух видах семейства Оrсhidaceae, ранее не указанных для флоры Казах-
стана. Среди них Neottia cordata с Маркаколького государственного заповедника (Восточный Ка-
захстан) и Hammarbya paludosa из Мугоджар (Западный Казахстан). Ближайшие ранее известные
местонахождения H. paludosa находятся на расстоянии более 500 км севернее публикуемой находки.
Ближайшее местонахождение N. cordata находится на территории России приблизительно в 300 км
северо-восточнее публикуемой находки. Новые местонахождения указанных видов определены на
основе исторических гербарных образцов 1908 и 1934 гг, обнаруженных в гербариях LE, NS и MW.

Ключевые слова: Listera cordata, Orchidaceae, Казахстанский Алтай, Мугоджары, новая находка, орхидея, Средняя Азия 